\title{
EMULSION OF SYSTEMS CONTAINING EGG YOLK, POLYSACCHARIDES AND VEGETABLE OIL
}

\author{
Emulsão de sistemas contendo gema de ovo, polissacarídeos e óleo vegetal
}

\author{
Clitor Junior Fernandes de Souza ${ }^{1}$, Edwin Elard Garcia Rojas ${ }^{2}$
}

\begin{abstract}
This work characterizes the emulsifying properties of systems containing egg yolk $(0.1 ; 1.0$ and $2.5 \% \mathrm{w} / \mathrm{v})$ and polysaccharides (xanthan gum, carrageen, pectin and carboxymethylcellulose) and three different vegetable oils (sunflower, canola, and palm oils). Emulsifying activity and emulsion stability were measured of each combination and it was found the effect of the oil on emulsion stability correlated to the amount of monounsaturated fatty acid. Additionally, increased egg yolk concentration increased emulsifying activity by reducing coalescence of oil droplets. Lastly, $2.5 \%$ egg yolk and $0.2 \%$ polysaccharide generated emulsions with high emulsifying activity, excellent stability, and droplet size of $4.32 \mu \mathrm{m}$.
\end{abstract}

Index terms: Modeling, emulsifying activity, hydrophilic properties.

\section{RESUMO}

Neste trabalho, caracterizam-se as propriedades emulsificantes de sistemas contendo gema de ovo $(0,1 ; 1,0$ e $2,5 \% \mathrm{~m} / \mathrm{v})$, polissacarídeos (goma xantana, carragena, pectina e carboximetilcelulose) e três diferentes óleos vegetais (óleos de palma, canola e girassol). Atividade emulsificante e estabilidade da emulsão foram medidas para cada combinação e verificou-se o efeito do óleo sobre a estabilidade da emulsão correlacionada com a quantidade de ácido graxo monoinsaturado. Além disso, a concentração de gema de ovo aumentou a atividade emulsificante, reduzindo a coalescência das gotículas de óleo. Por último, 2,5\% de gema de ovo e $0,2 \%$ de polissacarídeo formaram emulsões com alta atividade emulsificante, excelente estabilidade e tamanho de gota de 4,32 $\mu \mathrm{m}$.

Termos para indexação: Modelagem, atividade emulsificante, propriedades hidrofílicas.

(Received in august 6, 2012 and approved in august 13, 2012)

\section{INTRODUCTION}

An emulsion is a macroscopic dispersion of two liquids where one is a continuous part dispersed throughout small drops of the other (MORR, 1981). Proteins with an appreciable number of hydrophobic groups are effective emulsifying agents because they promote aggregation of oil droplets. However, proteins containing both hydrophobic and hydrophilic regions are superior emulsifiers because they significantly reduce load surface tension. This allows oil droplet breakage and formation of thin films around the surfaces of emulsified droplets (WALSTRA, 1983; TCHOLAKOVA; DENKOV; DANNER, 2004; WILDE et al, 2004).

Egg yolk proteins act as emulsifiers and are primarily livetins and low-density lipoproteins (LDL). The lipid in LDL consists of 70\% neutral lipid, 26\% phospholipids (71-76\%, phosphatidylcholine, 16-20\% phosphatidylethanolamine, and 8-9\% sphingomyelin and lysophospholipids), and 4\% free cholesterol (MINE; BERGOUGNOUX, 1998). Phospholipids, cholesterol, and both hydrophobic and hydrophilic proteins lend excellent emulsifying properties to egg yolk. The lipid fraction reduces the interfacial tension and facilitates fixation of macromolecules in the water-oil interface (MINE; BERGOUGNOUX, 1998; ALUKO; KEERATIURAI; MINE, 1998).

Interactions between anionic polysaccharide and protein form a conjugate which relies on hydrophilic properties of polysaccharides to thicken and stabilize aqueous medium adjacent to the emulsion interface. Therefore, it helps to stabilize drops formed by protein and prevent coalescence during the emulsification formation and subsequent storage (SHEPHERD et al., 1995; McCLEMENTS, 2004). Most hydrocolloids can act as stabilizers of oil-in-water emulsions, but only a few can act as emulsifiers. Functionality of emulsifiers demands a substantial surface activity at the oil-water interface, and the ability to facilitate the formation and stabilization of fine droplets during and after emulsification (WILLIAMS; PHILLIPS, 2004).

Emulsifier polysaccharides most often used in food are Arabic gum (CASTELLANI et al., 2010; CHAROEN et

1Universidade Federal Rural do Rio de Janeiro/UFRRJ - Seropédica - RJ - Brasil

¿Universidade Federal Fluminense/UFF - Departamento de Engenharia de Agronegócios - Avenida dos Trabalhadores - nº 420 - Santa Cecília 27255-125 - Volta Redonda - RJ - Brasil - edwin@vm.uff.br 
al., 2011), modified starch (MARTÍNEZet al., 2003; FARRAG 2008), modified cellulose (SUN et al., 2007; AMIRKHANIA et al., 2008), pectin (LITTOZA; McCLEMENTS, 2008; JONES; McCLEMENTS, 2010) and galactomannans (MIKKONENA et al., 2009; WUA et al., 2009). Protein ingredients derived from milk and/or egg, are commonly used as emulsifying agents (JONES; McCLEMENTS, 2010). Emulsion stability generally occurs according to the oil volume fraction, type of oil, temperature, $\mathrm{pH}$, type and quantity of emulsifier(s), ionic strength, and the presence of other ingredients such as sugar and carbohydrates (MORR, 1981; McCLEMENTS, 2005).

This objective of this work was to evaluate emulsifying properties of egg yolk and four anionic polysaccharides (xanthan gum, pectin, carboximethylcellulose, and carrageen) and three vegetable oils (sunflower, canola, and palm).

\section{MATERIAL AND METHODS}

\section{Materials}

Xanthan gum (Product number G1253 EC 234-3942), sodium carboximethylcellulose (Product number C4888500 ), pectin (Product number P9135), $\kappa$-carrageen (Product number C1013) and egg yolk (Product number EO-625) were obtained from Sigma-Aldrich (St. Louis, USA). Canola, sunflower, and palm oils were bought in the local store. For this experiment analytic grade reagents and deionized water were used.

\section{Preparation of aqueous polysaccharide solution}

The polysaccharide (PO) solution contained xanthan gum (XG), $\kappa$-carrageen (CA), carboximethylcellulose (CMC), and low metoxilation degree pectin (PEC). Polysaccharides were dissolved in buffer $(\mathrm{pH}$ 7.0) at a concentration of $1 \% \mathrm{w} / \mathrm{v}$ using an analytical balance (Tecnal, model B-TEC-210A, Brazil) with uncertainty of $\pm 0.0001 \mathrm{mg}$. The solution was then shaken for $3 \mathrm{hr}$ using a magnetic shaker (New Technique, model NT101, Brazil).

\section{Electric conductivity measurements}

Methods to evaluate emulsifications were adapted from previously described techniques (Al-MALAH; AZZAM; OMARI, 2000; AZZAM; OMARIA, 2002). Electrical conductivity (MCA 150, Tecnopon, Brazil) was used to extrapolate emulsifying properties of systems $(20 \mathrm{~mL})$ containing various concentrations of egg yolk $(0.1$; 1.0 and $2.5 \% \mathrm{w} / \mathrm{v})$ and polysaccharides $(0.1 ; 0.2$ and $0.4 \%$ $\mathrm{w} / \mathrm{v})$ in buffer ( $\mathrm{pH} 7.0)$. Canola, sunflower, or palm oil (7
$\mathrm{mL}$ ) was added to the protein-polysaccharide system and the two phases were homogenized for 2 min using an Ultra$\operatorname{Turrax}^{\circledR}$ (T 10 basic, IKA, Germany) at a speed of 18.600 rpm. Conductivity was measured during homogenization and 20 min afterward.

\section{Determination of emulsifying properties}

To determine emulsifying activity and emulsion stability, conductivity data measurements over time were divided in two stages respectively. The first stage was measured for all but the final $2 \mathrm{~min}$ of homogenization, and was used to determine emulsifying activity. The second stage began immediately after homogenization and was used to determine emulsion stability (ES) through the oil volume fraction of the creamed phase $(\Phi)$.

Kato et al. (1985) defined the emulsifying activity (EA) of a protein as the difference between conductivity of the protein solution prior to homogenization $\left(C_{0}\right)$ and the minimum conductivity achieved during homogenization $\left(C_{2}\right)$ (Equation 1).

$E A=C_{0}-C_{2}$

Anton and Gandemer (1997) proposed a mathematic model to determine $\Phi$ through its relationship with conductivity (Equation 2):

$\Phi=1-\left[(V / v)\left(1-C_{F} / C_{0}\right)\right]$

Where $V$ is the volume of the aqueous solution used in the emulsion formulation $(20 \mathrm{~mL}), v$ is the volume of used oil ( 7 $\mathrm{mL}), \mathrm{CF}$ is the conductivity of the emulsion and $C_{0}$ is the initial conductivity of the aqueous solution. All samples were made in duplicate and measurements were repeated twice. Statistical analyses were performed with $\mathrm{SAS}^{\circledR}$ software.

After evaluating the stability of the emulsion, microscopy was performed on a $1 \mathrm{~mL}$ aliquot to observe drop size and the distribution of the emulsion. Images were generated on an LV 150 (Nikon, USA) equipped with a 20x objective and assembled camera (DS-Fi1, Nikon, USA) and software (NSI-Elements D 3.0,USA).

\section{RESULTS AND DISCUSSION}

\section{Evaluation of emulsifying activity}

Figures 1, 2, and 3 summarize EA values as a function of EY concentration and that they gradually increase with 
increasing EY concentrations. Greater concentrations of protein molecules form more dense interfaces, which are absorbed more quickly around oil drops (formed during homogenization) and further reduce coalescence (SURH; DECKER; McCLEMENTS, 2006; DICKINSON, 2009). This is thought to occur due to the presence of amphipathic phospholipids in EY decreasing interfacial tension among formed oil drops (ALUKO; KEERATIURAI; MINE, 1998). Regarding polysaccharide concentration, greater concentrations of polysaccharides in the system reduce EA for the three studied protein concentrations (experiments 3, 6, and 9 in Figures 1 and 2; and experiments 6 and 9 of Figure 2). This observation may be due to increasing system viscosity leading to reduced adsorption of proteins on the surfaces of oil drops formed by homogenization (McCLEMENTS, 2006; WANG; WHANG; OZKAN, 2010). EINHORN-STOLL et al. (2005) observed that conjugates of whey protein isolate (WPI) with xanthan gum or pectin had lower emulsifying activity; however, the polysaccharide was capable of forming a strong 3dimensional network around the droplets which prevented coalescence.

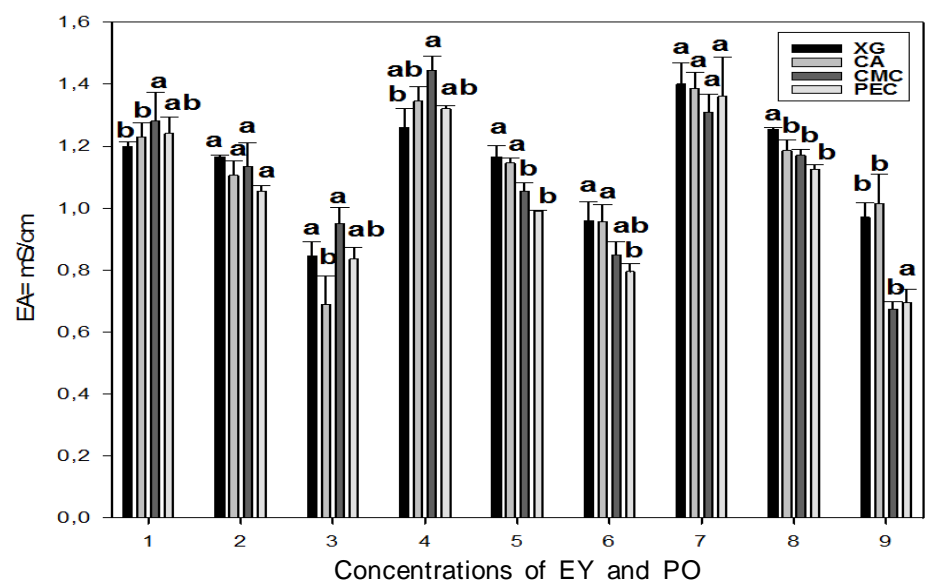

Figure 1 - Emulsifying activity of different concentrations of EY and PO with 7.0 mL palm oil. 1, 2 and $3(0.1 \% \mathrm{EY}: 0.1$, 0.2 and $0.4 \%$ PO, respectively); 4, 5 and 6 (1\% EY: 0.1, 0.2 and $0.4 \%$ PO, respectively); 7, 8 and 9 (2.5\% EY: 0.10 .2 and $0.4 \% \mathrm{PO}$, respectively).

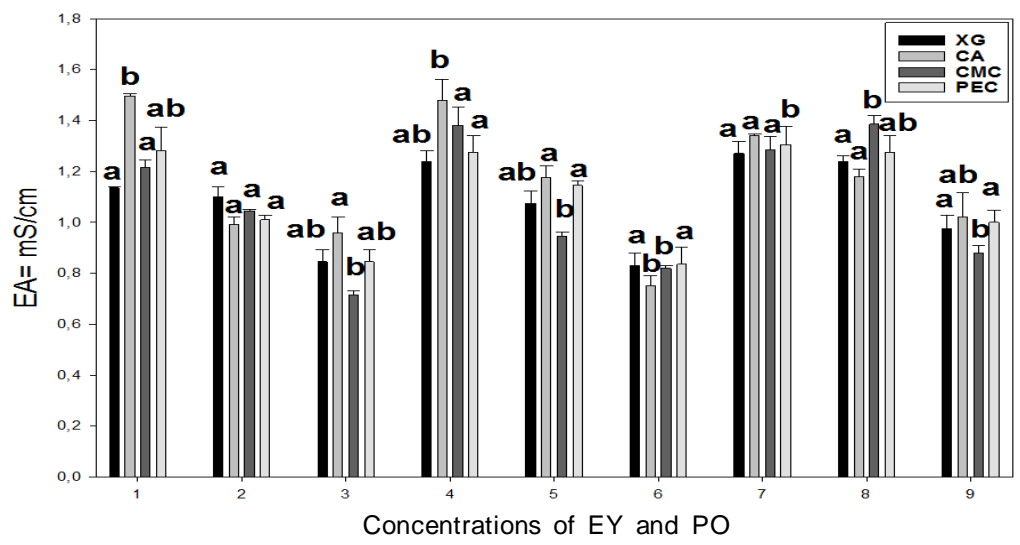

Figure 2 - Emulsifying activity of different concentrations of EY and PO with 7.0 mL sunflower oil. 1, 2 and 3 (0.1\% EY: $0.1,0.2$ and $0.4 \% \mathrm{PO}$, respectively); 4, 5 and 6 (1\% EY: $0.1 \%, 0.2$ and $0.4 \% \mathrm{PO}$, respectively); 7,8 and 9 (2.5\% EY: $0.1 \%$, 0.2 and $0.4 \% \mathrm{PO}$, Concentrations of $\mathrm{EY}$ and $\mathrm{PO}$ respectively). 


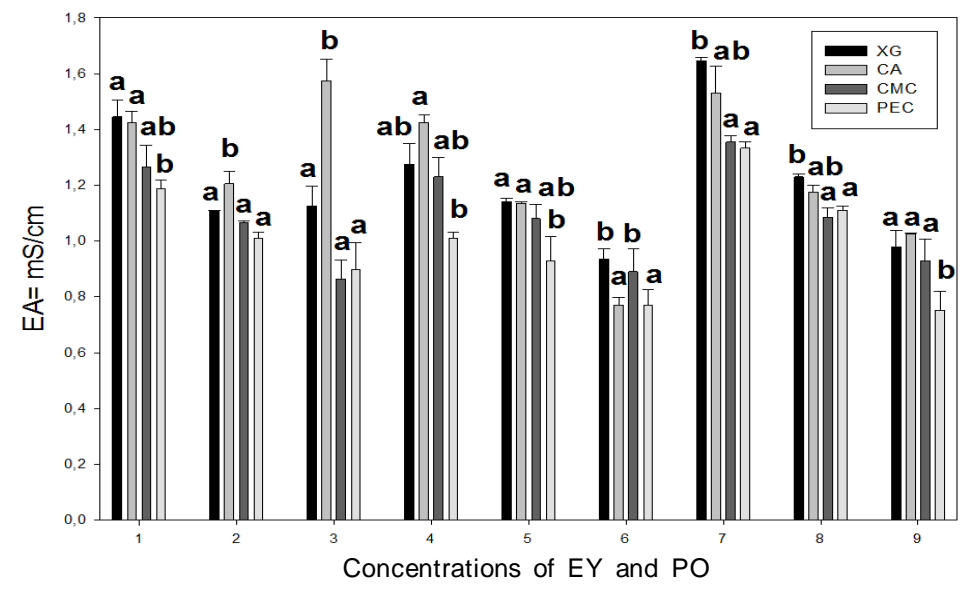

Figure 3 - Emulsifying activity of different concentrations of EY and PO with 7.0 mLcanola. 1, 2 and 3(0.1\% EY: 0.1, 0.2 and $0.4 \% \mathrm{PO}$, respectively); 4, 5 and 6 (1\% EY: $0.1 \%, 0.2$ and $0.4 \% \mathrm{PO}$, respectively); 7,8 and 9 (2.5\% EY and $0.1,0.2$ and $0.4 \% \mathrm{PO}$, respectively).

When the effect of oil type on EA is investigated, palm oil resulted in smaller EA values (around $1.4 \mathrm{mS} / \mathrm{cm}$ in the experiments 4 and 7) than sunflower or canola oils. The mechanism of this phenomenon is poorly understood, but Farr (2000) suggested that monounsaturated fatty acid, specifically oleic acid, further facilitates interactions between hydrophobic protein groups and oil droplets. This hypothesis is supported by the oleic acid content in canola oil [55-58\% (MORAES; BELL, 1993)] being greater than sunflower oil [35-45\% (BITTENCOURT; SADER; MORAIS, 1998)] and palm oil [15-25\% (BORA et al., 2003)].

Tukey tests $(\mathrm{p}<0.05)$ were used for means comparisons, where one can observe that some EA polymers showed the most significant $(\mathrm{p}<0.05)$ what for certain studied oils. The CA was more efficient emulsifier at lower concentrations $(0.1$ and $0.2 \%)$ for sunflower oil and $0.1 \%$ for canola oil. CMC was a superior emulsifier at $0.1 \%$ concentration for palm oil and $0.4 \%$ for sunflower oil. Finally, the PEC was superior at $0.4 \%$ concentration for sunflower oil and GX of $4.0 \%$ for canola oil.

\section{Emulsion stability}

Figure 4 shows photomicrographs of emulsions with their corresponding droplet size after homogenization. It can be clearly seen that different concentrations of OP and EY directly influenced the size of oil droplets and subsequently-studied ES.

Tables 1 to 3 present fractional volumes in the cream phase. While evaluating the effects of PO and EY concentrations for each one of the studied vegetable oils, lower values of $\Phi$ indicate better emulsion stability. Canola oil was the one gave the lowest values of $\Phi$ because of its high fraction of monounsaturated fatty acids.

Figure 4 (A and $\mathrm{C}$ ) shows that low concentrations of polysaccharide (CMC) and 1.0\% EY were not sufficiently to confer EA (Figure 2), leading to instability in the formed emulsion (Table 2) with a considerably larger droplet diameter. This is primarily because low protein concentrations are inefficient and form layers around the oil droplets. As the number of hydrophobic connections around droplet is insufficient, coalescence gradually increases until the emulsion collapses and phase separation occurs (McCLEMTS, 2006; JONES; McCLEMENTS, 2010). However, Figure 4B shows that $0.2 \% \mathrm{XG}$ and $2.5 \% \mathrm{EY}$, which have high EA, led to a considerable reduction in droplet diameter and subsequently higher stability (RANGSANSARID; FUKADA, 2007; ANTON; GANDEMER, 1997; LIZARRAGA; PAN; SANTIAGO, 2008). Reduced coalescence caused by the interaction of a thin protein layer around the droplets with the three-dimensional polysaccharide network bound to water (TIPPETTS; MARTINI, 2012).

Polynomial model for the oil volume fraction of the creamed phase $\Phi$, as a function of mass of egg yolk and polysaccharides, was fitted to the experimental data. The general quadratic model (Equation 3) was first analyzed and the no significant parameters were eliminated on the basis of the t-test with $p>0.05$. Table 4 shows the predictive models based on equation model (3) for each used oil. 
$\Phi=\beta_{o}+\beta_{1} w_{1}+\beta_{2} w_{2}+\beta_{3} w_{1}^{2}+\beta_{4} w_{1} w_{2}+\beta_{5} w_{2}^{2}+$ $\beta_{6} w_{1}^{2} w_{2}+\beta_{7} w_{2}^{2} w_{1}$

where $\Phi$ is the oil volume fraction of the creamed phase, $w_{1}$ is the mass of egg yolk lipoprotein, $w_{2}$ is the mass of polysaccharides and $\beta_{1}, \beta_{2}, \beta_{3}, \beta_{4}, \beta_{5}, \beta$, and $\beta_{7}$ were obtained by nonlinear regression. The mathematical polynomial model was well adjusted to the experimental data, as observed in table 4 . This is an indicative of a good fit to the experimental data.
Statistical analyses revealed that each polysaccharide generated emulsifications with different characteristics using the different oils. This behavior is primarily due to the inherent characteristics of two studied polysaccharides: (i) the non-polar chemical groups attached to different hydrophilic polysaccharide backbone, or (ii) the presence of a protein component covalently or physically bound to the polysaccharide (DICKINSON, 2009).
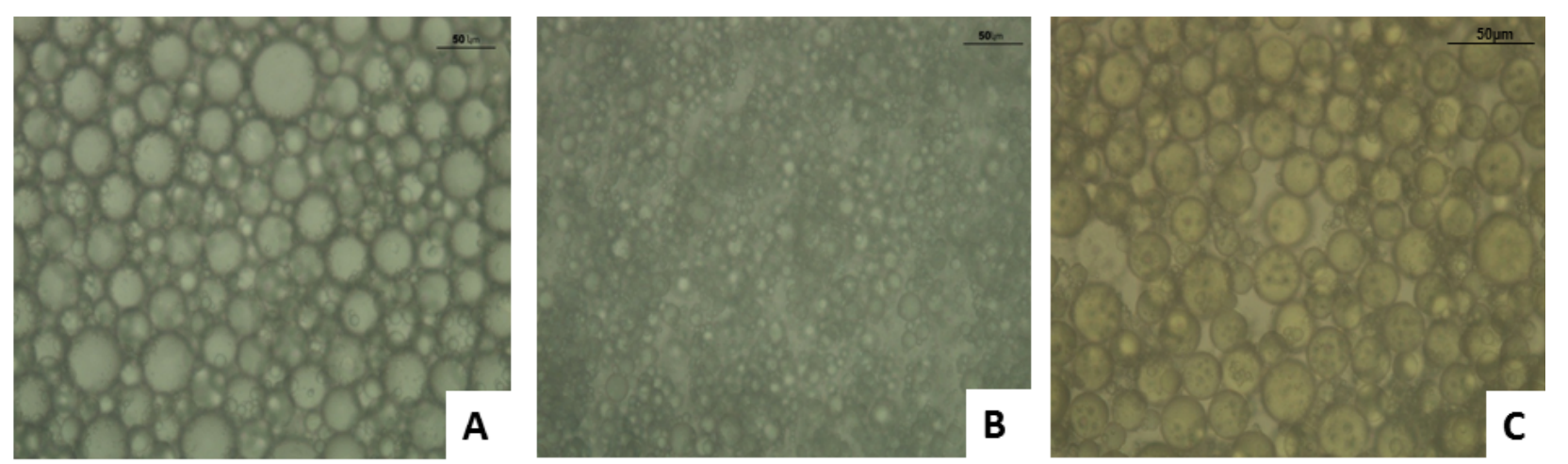

Figure 4 - Photomicrographs of emulsions with their respective concentrations and mean droplets diameter. A $(0.1 \%$ $\mathrm{CMC} / 0.1 \% \mathrm{EY} /$ Sunflower. Diameter $=27.10 \mu \mathrm{m}) ; \mathrm{B}(0.2 \% \mathrm{GX} / 2.5 \% \mathrm{EY} /$ Canola. Diameter $=4.32 \mu \mathrm{m}) ; \mathrm{C}(0.4 \% \mathrm{CMC} /$ $0.1 \% \mathrm{EY} /$ Palm oil. Diameter $=24.29 \mu \mathrm{m})$.

Table $1-\Phi$ values for systems using palm oil in different concentrations of egg yolk and polysaccharides.

\begin{tabular}{|c|c|c|c|c|c|}
\hline \multicolumn{2}{|c|}{ Palm oil } & $X G$ & CA & CMC & PEC \\
\hline Egg Yolk (\%) & Polysaccharides $(\%)$ & $\Phi$ & $\Phi$ & $\Phi$ & $\Phi$ \\
\hline 0.1 & 0.1 & 0.1478 & 0.2084 & 0.0867 & 0.0325 \\
\hline 0.1 & 0.2 & 0.1194 & 0.2047 & 0.1488 & 0.154 \\
\hline 0.1 & 0.4 & 0.2940 & 0.4334 & 0.2503 & 0.2638 \\
\hline 1.0 & 0.1 & 0.1184 & 0.1305 & 0.0498 & 0.0498 \\
\hline 1.0 & 0.2 & 0.1428 & 0.1857 & 0.2271 & 0.2396 \\
\hline 1.0 & 0.4 & 0.2255 & 0.2912 & 0.2960 & 0.3197 \\
\hline 2.5 & 0.1 & 0.0771 & 0.1087 & 0.1512 & 0.0909 \\
\hline 2.5 & 0.2 & 0.1262 & 0.2252 & 0.1766 & 0.1541 \\
\hline 2.5 & 0.4 & 0.3528 & 0.2685 & 0.4464 & 0.3945 \\
\hline
\end{tabular}


Table $2-\Phi$ values for systems using sunflower oil in different concentrations of egg yolk and polysaccharides.

\begin{tabular}{cccccc}
\hline & Sunflower oil & XG & CA & CMC & PEC \\
\hline Egg Yolk (\%) & Polysaccharides $(\%)$ & $\Phi$ & $\Phi$ & $\Phi$ & $\Phi$ \\
\hline 0.1 & 0.1 & 0.1904 & 0.3802 & 0.1512 & 0.1435 \\
0.1 & 0.2 & 0.3216 & 0.2820 & 0.2105 & 0.1988 \\
0.1 & 0.4 & 0.2940 & 0.2966 & 0.4309 & 0.2857 \\
1.0 & 0.1 & 0.1281 & 0.0644 & 0.8538 & 0.9062 \\
1.0 & 0.2 & 0.2148 & 0.1871 & 0.9964 & 0.1398 \\
1.0 & 0.4 & 0.3517 & 0.4145 & 0.3341 & 0.2941 \\
2.5 & 0.1 & 0.1600 & 0.1572 & 0.1693 & 0.1288 \\
2.5 & 0.2 & 0.1683 & 0.2322 & 0.7807 & 0.0960 \\
2.5 & 0.4 & 0.2746 & 0.3205 & 0.3466 & 0.2045 \\
\hline
\end{tabular}

Table $3-\Phi$ values for systems using canola oil in different concentrations of egg yolk and polysaccharides.

\begin{tabular}{cccccc}
\hline & Canola oil & XG & CA & CMC & PEC \\
\hline Egg Yolk (\%) & Polysaccharides $(\%)$ & $\Phi$ & $\Phi$ & $\Phi$ & $\Phi$ \\
\hline 0.1 & 0.1 & 0.0216 & 0.1051 & 0.1163 & 0.1855 \\
0.1 & 0.2 & 0.1609 & 0.1442 & 0.2075 & 0.2352 \\
0.1 & 0.4 & 0.2762 & 0.1037 & 0.3496 & 0.1445 \\
1.0 & 0.1 & 0.1058 & 0.1071 & 0.1921 & 0.9828 \\
1.0 & 0.2 & 0.1690 & 0.2170 & 0.8634 & 0.2564 \\
1.0 & 0.4 & 0.2913 & 0.4351 & 0.3013 & 0.3284 \\
2.5 & 0.1 & 0.0219 & 0.0339 & 0.1260 & 0.0996 \\
2.5 & 0.2 & 0.1449 & 0.2282 & 0.8729 & 0.2004 \\
2.5 & 0.4 & 0.2838 & 0.2993 & 0.3007 & 0.3524 \\
\hline
\end{tabular}

Table 4 - Models to calculate oil volume fraction of the emulsions creamed phase $\Phi,(\mathrm{p}>0.05)$.

\begin{tabular}{|c|c|c|c|c|c|c|c|c|c|}
\hline Óil - Polymer & $\beta_{o}$ & $\beta_{1}$ & $\beta_{2}$ & $\beta_{3}$ & $\beta_{4}$ & $\beta_{5}$ & $\beta_{6}$ & $\beta_{7}$ & $R^{2}$ \\
\hline Canola-CA & 0.0856 & -0.6712 & - & - & 57.1017 & - & -49.2463 & -231.668 & 0.96 \\
\hline Canola-CMC & -0.0593 & - & 3.7310 & -4.6188 & 164.7831 & - & - & -1701.272 & 0.83 \\
\hline Canola-PEC & 0.1273 & 6.9271 & - & -14.2666 & - & - & - & - & 0.70 \\
\hline Canola-GX & -0.8069 & - & 3.7910 & -0.0679 & - & - & - & - & 0.93 \\
\hline Palm oil-CA & 0.1712 & -0.4760 & - & - & - & 43.6858 & 18.7857 & -239.0339 & 0.98 \\
\hline Palm oil-CMC & 0.0524 & - & 2.3416 & - & - & - & - & 62.3643 & 0.92 \\
\hline Palm oil - PEC & -0.1025 & - & 8.8975 & - & - & - & - & 39.6230 & 0.94 \\
\hline Palm oil - GX & 0.1273 & 6.9271 & - & -14.2664 & - & - & - & - & 0.70 \\
\hline Sunflower oil-CA & 0.44387 & -3.6686 & -2.3249 & 6.0140 & 61.1901 & - & -102.4876 & - & 0.97 \\
\hline Sunflower oil-CMC & -0.1859 & 8.0792 & 7.9053 & -19.4095 & - & - & 256.8306 & -1381.6893 & 0.99 \\
\hline Sunflower oil-PEC & - & - & - & - & - & - & - & - & - \\
\hline Sunflower oil-GX & 0.0591 & -0.9163 & 9.9757 & 2.2579 & - & -89.6515 & -43.7235 & 236.5108 & 0.98 \\
\hline
\end{tabular}




\section{CONCLUSIONS}

This study examined EY concentration and polysaccharide species in formation of emulsions. We observed that the combination of low EY concentrations with low polysaccharide concentrations resulted in unstable emulsions with large droplet size. However, higher EY and polysaccharide concentrations yielded stable emulsions. It is clear that oil, specifically monounsaturated fatty acids, are extremely important in emulsion formation and facilitate the emulsification process. The polynomial model used to predict the volume fraction of the cream oil phase of emulsions had a good fit to the experimental data and holds promise for further studies to assess the functional properties of this new emulsion.

\section{ACKNOWLEDGMENTS}

The authors are grateful to CNPq and FAPERJ for the financial support.

\section{REFERENCES}

Al-MALAH, K.I.; AZZAM, M.O.J.; OMARI, R.M. Emulsifying properties of BSA in different vegetable oil emulsions using conductivity technique. Food

Hydrocolloids, v.14, p.485-490, London, Sep. 2000.

ALUKO, R.E.; KEERATIURAI, M.; MINE, Y.

Competitive adsorption between egg yolk lipoproteins and whey proteins on oil-in-water interfaces. Colloids and Surfaces B: Biointerfaces, London, v.10, p.385-393, May. 1998.

AMIRKHANIA, M. et al. Adsorption of cellulose derivatives on flat gold surfaces and on spherical gold particles. Journal of Colloid and Interface Science, London, v.328, p.20-28, Dec. 2008.

ANTON, M.; GANDEMER, G. Composition, solubility and emulsifying properties of granules and plasma of hen egg yolk. Journal of Food Science, Malden v.62, p.484-487, Jul. 1997.

AZZAM, M.O.J.; OMARIA, R.M. Stability of egg whitestabilized edible oil emulsions using conductivity technique. Food Hydrocolloids, London, v.16, p.105-110, Mar. 2002.

BITTENCOURT, J.F.N.; SADER, R.; MORAES, R.M. Variation of protein, oil and oleic acid values during the growth of sunflower seeds. Brazilian Magazine of Seeds, Brasilia, v.12, p.76-88, March, 1998.

BORA, P.S et al. Characterization of principal nutritional components of Brazilian oil palm (Eliaes guineensis) fruits. Bioresource Technology, London, v.87, p.1-5. Mar. 2003.

CASTELLANI, O. et al. Hydrocolloids with emulsifying capacity. Part 1 - Emulsifying properties and interfacial characteristics of conventional [Acacia senegal (L.) Willd. var. senegal] and matured [Acacia (sen) SUPER GUM $^{\mathrm{TM}}$ ) Acacia senegal. Food Hydrocolloids, London, v.2, p.193-199, Mar.-May, 2010.

CHAROEN, R. et al. Influence of biopolymer emulsifier type on formation and stability of rice bran oil-in-water emulsions: whey protein, gum arabic, and modified starch. Journal of Food Science, Malden, v.76, p.E165E172, Jan. 2011.

DICKINSON, E. Hydrocolloids as emulsifiers and emulsion stabilizers. Food Hydrocolloids, London, v.23, p.1473-1482, Aug. 2009.

EINHORN-STOLL, U. et al. Formation of milk proteinpectin conjugates with improved emulsifying properties by controlled dry heating. Food Hydrocolloids. London, v.19, p.329-340, Jul. 2005.

FARR, W.E. Refining of fats and oils. In: O'Brien RDO, Farr WE and Wan PJ (eds) Introduction to fats and oils technology. 2nd ed. Illinois: AOCS Press, p.136-157, 2000.

FARRAG, A.F. Emulsifying and foaming properties of whey protein concentrates in the presence of some carbohydrates. International Journal of Dairy Science, London, v.3, p.20-28, March, 2008.

JONES, O.G.; McCLEMENTS, D.J. Functional biopolymer particles: design, fabrication, and applications. Comprehensive Reviews in Food Science and Food Safety, Malden, v.9, p.374-397, Jul. 2010.

KATO, A.; FUJISHIGE, T.; MATSUDOMI, N.; KOBAYASHI, K. Determination of emulsifying properties of some proteins by conductivity measurements. Journal of Food Science, Malden, v.50, p.56-62, Jan. 1985. 
LITTOZA, F.; McCLEMENTS, D.J. Bio-mimetic approach to improving emulsion stability: Cross-linking adsorbed beet pectin layers using lactase. Food Hydrocolloids, London, v.22, p.1203-1211, Jun. 2008.

LIZARRAGA M.S.; PAN, L.G;; AÑON, M.C.; SANTIAGO, L.G. Stability of concentrated emulsions measured by optical and rheological methods. Effect of processing conditions-I. Whey protein concentrates. Food Hydrocolloids, London, v.22, p.868-878, Apr. 2008.

MARTÍNEZ, I. et al. Influence of thermal treatment on the flow of starch-based food emulsions. European Food Research and Technology, London, v.217, n.1, p.17-22, May, 2003.

McCLEMENTS, D.J. Protein-stabilized emulsions. Current Opinion in Colloid and interface Science, London, v.9, p.305-313, Jun. 2004.

McCLEMENTS, D.J. Food emulsions: principles, practices, and techniques. Boca Raton: Fla. 2006. p.35291.

MIKKONENA, K.S. et al. Mannans as stabilizers of oilin-water beverage emulsions. LWT - Food Science and Technology, London, v.42, p.849-855, May, 2009.

MINE Y.; BERGOUGNOUX, M. Adsorption properties of cholesterol reduced egg yolk low-density lipoprotein at oil-in- water interfaces. Journal of Agriculture Food Chemistry, California, v.46, p.2152-2158, Jun. 1998.

MORAES, M.; BELL J.M. Factor affecting the nutritional value of canola meal: a review. Canadian Journal of Animal Science, Canada, v.73, n.3, p.679697, Jun. 1993.

MORR, C.V. Emulsifiers: Milk Proteins. In: CHERRY, J. P. Protein Functionality in Foods, Clemson, American Chemical Society, v.147, p.201-215, 1981.

RANGSANSARID, J.; FUKADA, K. Factors affecting the stability of $\mathrm{O} / \mathrm{W}$ emulsion in BSA solution: stabilization by electrically neutral protein at high ionic strength. Journal of Colloid and Interface Science, London, v.316, p.779-786, Jul. 2007.

SAS Institute Inc. SAS ${ }^{\circledast}$ User's guide: Statistics, North Caroline, v.8, 1999.
SHEPHERD, R. et al. ROCKEY, J.; SUTHERLAND, I.W.; ROLLER, S. Novel bioemulsifiers from microorganisms for use in foods. Journal of Biotechnology, Malen, v.40, p.207-217, Jun. 1995.

SUN, W. et al. Oil-in-water emulsions stabilized by hydrophobically modified hydroxyethyl cellulose: adsorption and thickening effect. Journal of Colloid Interface Science, London, v.1, p.28-36, Jul. 2007.

SURH, J.; DECKER, E.A.; McCLEMENTS, D.J. Properties and stability of oil-in-water emulsions stabilized by fish gelatin. Food Hydrocolloids, London, v.20, p.596-606, Aug. 2006.

TCHOLAKOVA, S.; DENKOV, N.D.; DANNER, T. Role of surfactant type and concentration for the mean drop size during emulsification in turbulent flow. Langmuir, Washington, v.20, n.18, p.7444-7458, Aug. 2004.

TIPPETTS, M.; MARTINI, S. Influence of $\kappa$-Carrageenan, pectin, and gelatin on the physicochemical properties and stability of milk protein-stabilized emulsions. Journal of Food Science. London, v.77, n.2, p.C253-C260, Mar. 2012.

WALSTRA, P. Formation Emulsion. In: BECHER, P. (ed.), Encyclopedia of Emulsion Technology. New York. Marcel Dekker. 1983. p.57-127.

WANG, B.; LI, D.; WANG, L.J.; ÖZKAN, N. Effect of concentrated flaxseed protein on the stability and rheological properties of soybean oil-in-water emulsions. Journal of Food Engineering, London, v.96, n.4, p.555561, Sep. 2010.

WILDE, P. et al. Proteins and emulsifiers at liquid interfaces. Advances in Colloid and Interface Science. London, v.118-119, p.67-71, Jul. 2004.

WILLIAMS, P.A.; PHILLIPS, G.O. Gums and stabilizer's for the food industry. In: DICKINSON, E. Effect of hydrocolloids on emulsion stability, Cambridge, 2004. p.394-404.

WUA, Y.; CUIA, W. ESKINB, N.; GOFFC, H.D. An investigation of four commercial galactomannans on their emulsion and rheological properties. Food

Research International, London, v.42, p.1141-1146, may, 2009. 